\title{
Return On Equity Terhadap Kinerja Perbankan Dan Nilai Emas Sebagai Variabel Moderasi
}

\author{
${ }^{1}$ Edi Winarto \\ ${ }^{2}$ Suryadi \\ Jurusan Akuntansi, Politeknik Negeri Malang \\ Jl. Soekarno Hatta No.9, Jatimulyo, Kec. Lowokwaru, Malang, \\ Jawa Timur 65141 \\ Email : erwinramadhani94@gmail.com
}

\begin{abstract}
Abstrak
Penelitian ini bertujuan untuk mengetahui pengaruh Return on Equity terhadap kinerja perbankan yang dinilai dengan Tobin's Q melalui nilai emas, apakah pengaruh secara langsung maupun tidak langsung. Jenis penelitian yang digunakan adalah explanatory research dengan pendekatan kuantitatif. Populasi yang digunakan dalam penelitian ini adalah perusahaan sektor perbankan adalah 40 yang terdaftar di BEI periode 2013 s/d 2018. Teknik pengambilan sampel mengunakan purposive sampling sehingga sampel terpiih berjumlah 29. Penelitian ini menggunakan analisis data statistik deskriptif dan analisis jalur (part analysis). Hasil menunjukkan bahwa ROE pengaruh negatif yang tidak signifikan sedangkan Emas terhadap Q pengaruh negatif yang signifikan, Koefisien tidak langsung adalah 0,02139 dan Pengaruh Total adalah $-0,02261$, berarti hubungan yang sebenarnya adalah hubungan tidak langsung lebih baik mempengaruhi Tobin's Q (Kinerja Perbankan) yang berarti pula secara tidak langsung variabel nilai emas dapat mendorong pengaruh terhadap Kinerja Perusahaan.

Kata Kunci: ROE, EMAS, Tobin's $Q$
\end{abstract}

\begin{abstract}
This study purposes to determine the effect of Return on Equity on banking performance assessed by Tobin's $Q$ through the value of gold, whether direct or indirect influence. This type of research is an explanatory research with a quantitative approach. The population used in this study were 40 banking sector companies listed on the Indonesia Stock Exchange from 2013 to 2018. The sampling technique used purposive sampling so that the chosen sample was 29. This study used descriptive statistical data analysis and part analysis. The results
\end{abstract}


show that ROE is not a significant negative effect while Gold on $Q$ is a significant negative effect, the indirect coefficient is 0.02139 and the Total Effect is -0.02261, it means that the actual relationship is an indirect relationship better affecting Tobin's $Q$ (Banking Performance) which also means that indirectly the gold value variable can drive influence on Company Performance.

Keywords: ROE, GOLD, Tobin's $Q$

\section{PENDAHULUAN}

Perkembangan harga saham suatu perusahaan mencerminka nilai saham perusahaan, sehingga kemakmuran dari pemegang saham dicerminkan dari harga sahamnya (Suad, 2001). Harga saham dapat fluktuasi darei waktu ke waktu, fluktuasi harga saham dapat dipengaruhi oleh faktor ekternal maupun faktor internal perusahaan. Faktor ekternal perusahaan diantaranya adalah tingka perkembangan inflasi, nilai tukar atau kurs rupiah, keadaan perekonomian, dan kondisi sosial politik suatu negara, sedangkan faktor internal perusahaan diantaranya kondisi fundamental perusahaan, kebijakan direksi dan lain-lain. Dalam pengembilan keputusan membeli saham investor akan mempelajari mengenai kondisi perusahaan. Analisis sebelum melakukan pilihan atas saham yang akan dibeli merupakan analisis fundamental atau merupakan analisis teknikal. Analisis fundamental menurut Suad (2001) merupakan analisis historis atas kondisi internal perusahaan, analisis fundamental memiliki pedoman pada suatu kepercayaan bahwa nilai suatu saham dapat dipengaruhi oleh kinerja perusahaan yang mengeluarkan saham tersebut.

Pada Nilai Perusahaan pada dasarnya dapat diukur melalui beberapa aspek, salah satunya harga pasar saham perusahaan, karena harga pasar saham akan mencerminkan penilaian investor keseluruhan atas setiap ekuitas yang dimiliki untuk mendapatkan laba. Selain mendapatkan laba, tujuan pokok perusahaan adalah untuk memaksimlakn nilai perusahaan (Husnan, 2006). Memaksimalkan nilai perusahaan berarti memaksimalkan nilai sekarang dari semua keuntungan yang akan diterima oleh investor di masa yang akan datang (Sudana, 2009) Suatu nilai perusahaan pastinya berorientasi jangka panjang dan setiap pengambilan keputusan atas kebijakan dilakukan oleh perusahaan harus mempertimbangkan nilai perusahaan.

Nilai perusahaan dapat diketahui dengan menghitung rasio Tobin's Q. Rasio Tobin's Q merupakan rasio yang dikemukakan oleh Tobin's Rasio ini akan menggabarkan bagaimana keefektifitasan manajemen dalam mengelola sumber daya yang dimiliki oleh perusahaan dengan 
membandingkan nilai pasar saham yang dijumlahkan hutang dan dibagi total aset perusahaan, semakin tinggi rasio Tobin's Q maka semakin mampu pula perusahan untuk meningkatkan nilai perusahaan.

Terdapat tiga faktor yang dapat mempengaruhi nilai perusahaan yaitu Leverage keuangan Profitabilitas (Khatab dkk, 2011) dan Ukuran perusahaan (Siahaan, 2013) 5. Faktor faktor ini merupakan bahan pertimbangan manajemen untuk membuat kebijakan bagi perusahaan untuk memaksimalkan nilai perusahaan tentu banyak faktor lain yang memberikan pengaruh terhadap nilai perusahaan, Khatab et.al (2011) menunjukkan bahwa ROA dan ROE berpengaruh positif terhadap nilia perusahaan. Saleem dan Rahmat (2011) secara empiris menunjukkan adanya hubungan antara rasio likuiditas dan rasio profitabilitas yang memberikan dampak pada peningkatan nilai perusahaan. Sedangkan hasil penelitian Bodie et al (2003) menyatakan bahwa harga emas saham dipengaruhi juga oleh kinerja ekonomi makro yakni emas, disamping itu Mishra (2010) menyatakan bahwa harga emas cenderung meningkat secara stabil dikarenakan tingginya permintaan akan emas dan merupakan komoditas yang aman dan hampir tidak memiliki risiko. Berarti nilai emas merupakan komoditi yang memiliki nilai lindung yang sangat baik terhadap inflasi dan dapat melindungi pendapatan di masa depan. Ini artinya ROE dan Emas berpotensi dapat mempengaruhi nilai perusahaan-(Tobin's Q).

Faktor fundamental internal perusahaan berhubungan dengan setiap faktor yang dapat mempengaruhi kemampuan perusahaan dan faktor yang dapat mempengaruhi kemampuan perusahaan menciptakan aliran tunai bersih dalam perusahaan untuk didistribusikan kepada para pemegang saham sebagai deviden. Faktor fundamental ekonomi makro dimana kondisi ekonomi makro dapat semakin mendorong terciptanya aliran tunai bersih perusahaan, maka faktor ekonomi makro akan semakin mendorong peningkatan harga saham atau sebaliknya akan menyebabkan terjadinya penurunan harga saham.

Dalam jangka panjang naik turunya harga saham dipengaruhi oleh sektor riil ekonomi atau sektor keuangan atau bahkan keduanya. Sektor riil ekonomi yang dapat mempengaruhi misalnya seperti faktor harga emas. Dalam penelitian Sambodo (2014) ada menyatakan bahwa emas merupakan salah satu komoditi penting yang dapat mempengaruhi pergerakan bursa saham. Hal ini didasari bahwa emas merupakan salah satu alternatif investasi yang cenderung aman dan bebas resiko. Jenis emas ini adalah yang terbaik untuk melakukan investasi karena dimana pun dan kapan pun investor ingin menjualnya, nilainya akan selalu sama. Menurut beberapa teori dan penelitian terdahulu emas dan saham merupakan jenis barang yang bersifat substitusi. Artinya, ketika investasi saham dianggap tidak 
menguntungkan investor cenderung mengalihkan dana yang dimilikinya dalam bentuk investasi emas, begitu pula kebalikanya. Menurut Sarfaraz et al. (2005) faktor yang mempengaruhi naik turunnya harga emas antara lain moneter, politik, stabilitas ekonomi. Sedangkan menurut Ranson et al. (2005) harga minyak yang cenderung meningkat memungkinkan terjadinya tekanan inflasi, yang pada gilirannya dapat mengakibatkan meningkatnya harga emas karena adanya peningkatan penggunaan emas sebagai lindung nilai inflasi. Fenomena yang terjadi investasi emas atau beli saham, Fei \& Kelichi (2010) menekankan bahwa emas memiliki common-wisdom "theories" yakni (1) Orang-orang menganggap emas merupakan simbol kekayaan abadi. Emas merupakan "safe heaven" dalam pasar keuangan, (2) Emas merupakan "nilai lindung inflasi". Emas merupakan salah satu bentuk investasi yang cenderung bebas resiko (Sunariyah, 2006). Emas banyak dipilih sebagai salah satu bentuk investasi karena nilainya cenderung stabil dan naik. Emas adalah alat yang dapat digunakan untuk menangkal inflasi yang kerap terjadi setiap tahunnya. Ketika akan berinvestasi, investor akan memilih investasi yang memiliki tingkat imbal balik tinggi dengan resiko tertentu atau tingkat imbal balik tertentu dengan resiko yang rendah. Investasi di pasar saham tentunya lebih berisiko daripada berinvestasi di emas, karena tingkat pengembaliannya yang secara umum relatif lebih tinggi dari emas. Investasi dalam bentuk emas merupakan investasi komoditas yang sangat likuid karena di negara manapun emas dapat diterima.

Dalam hal ini harga emas diduga dapat memperkuat atau memperlemah variabel independen Dividen Payout Ratio (DPR) dan Debt to Equity Ratio (DER) dalam memengaruhi harga saham dan juga pada nilai perusahaan sektor perbankan yang terdaftar di BEI. Ke dua variabel yang digunakan dalam penelitian ini menujukkan bahwa bagaimana rumusan masalah dari penelitian ini dibatasi pada return on equity, dimana Variabel ROE yang mewakili Return dan variabel harga emas sebagai variabel moderasi yang menunjukkan peningkatan/penurunan kinerja dari sebuah perusahaan sektor perbankan. Harapan dalam penelitian ini adalah Rasio Profitabilas dapat menjelaskan perubahan kinerja perusahaan melalui harga emas. Dengan demikian variabel Nilai emas dapat mempengaruhi nilai perusahaan secara langsung atau tidak langsung, menurut Sugiyono (2001), variabel pemoderasi adalah variabel yang mempengaruhi (memperlemah atau memperkuat) hubungan antara variabel independen dengan variabel dependen.

\section{TINJAUAN PUSTAKA}

Menurut pendapat Modigliani dan Miller (MM) dalam Van Horne, C bahwa nilai perusahaan ditentukan hanya oleh kemampuan menghasilkan laba dari asset - asset perusahaan atau kebijakan investasinya, dan bahwa cara aliran laba dipecah antara deviden dan laba ditahan tidak 
mempengaruhi nilai ini. Mereka juga mengatakan bahwa berdasarkan keputusan investasi perusahaan, rasio pembayaran deviden hanyalah rincian dan tidak memengaruhi kesejahteraan pemegang saham. MM membuat asumsi ini tidak ada pajak penghasilan atas deviden, tidak ada biaya transaksi jual beli saham dan adanya informasi yang simetris antara pemegang saham dengan manajemen.

Berdasarkan asumsi ini pemegang saham akan mengabaikan antara deviden atau laba ditahan, karena pemegang saham dapat menjual saham pada porsi tertentu untuk mendapat kas sebagai pengganti dividen kas. Sebaliknya apabila perusahaan membagikan dividen pada hal pemegang saham tidak membutuhkan kas, maka pemegang saham dapat membeli saham sebagai penempatan kas yang diterima dari dividen kas.

Pada dasarnya asumsi itu berbanding terbalik dengan kenyataan yang menyatakan bahwa pasar modal yang sempurna sulit ditemui, biaya emisi saham baru pasti ada, pajak pasti ada dan kebijakan perusahaan tidak mungkin tidak berubah. Beberapa ahli menentang pendapat MM tentang dividen adalah tidak relevan dengan menunjukkan bahwa adanya biaya emisi saham baru akan mempengaruhi nilai perusahaan. Berdasarkan teori kebijakan deviden terdapat dua teori yaitu: (1) Bird in the hand theory: Teori ini dikemukakan oleh Myron Gordon dan John Lintner, menurut Brigham (2011) berdasar teori bird in the hand ini kebijakan deviden berpengaruh positif terhadap harga saham. Artinya, jika deviden yang dibagikan perusahaan semakin besar, harga pasar saham perusahaan tersebut akan semakin tinggi dan sebaliknya. Hal ini karena pembagian dividen dapat mengurangi ketidakpastian yang dihadapi investor. Investor akan memberikan nilai lebih tinggi kepada dividen yield daripada capital gain yang diharapkan dari pertumbuhan harga saham apabila perusahaan menahan laba untuk dipakai membelanjai investasi, karena komponen dividen yield resikonya lebih kecil dibandingkan dengan komponen pertumbuhan pada pendapatan yang di inginkan; (2) Clientle Effect Theory: Menurut Brigham (2011) teori ini menyatakan bahwa kelompok pemegang saham (clientele) yang berbeda akan memiliki preferensi yang berbeda terhadap kebijakan dividen perusahaan. Investor memiliki orientasi bermacam-macam dalam berinvestasi, ada investor yang mengejar dividend dan ada yang menyukai untuk menginvestasikan kembali pendapatanya karena investor tersebut berada dalam tarif pajak yang tinggi. Dua kelompok investor ini memiliki dua kepentingan berbeda dan cenderung bertentangan dalam hal pembagian dividend dan tarif atas dividen tersebut.

\section{Nilai Perusahaan}

Nilai perusahaan merupakan kondisi yang dicapai oleh suatu perusahaan atas kepercayaan masyarakat terhadap perusahaan karena suatu 
proses kegiatannya sejak berdiri sampai dengan sekarang. Nilai perusahaan ini merupakan persepsi investor terhadap tingkat keberhasilannya terkait dengan harga saham yang cenderung tinggi maka nilai perusahaan ini relatif tinggi pula.

\section{Profitabilitas}

Merupakan rasio yang menggambarkan kinerja fundamental perusahaan ditinjau dari tingkat efisiensi dan efektivitas opereasi yang dijalankan perusahaan untuk memperoleh laba, Bagi perusahaan profitabilitas menjadi salah satu pertimbangan yang sangat penting disamping terkait laba, karena ukuran efisien tidak terbatas pada besarnya laba. Efisiensi baru dapat diketahui dengan membandingkan laba yang diperoleh dengan modal atau kekauyaan yang digunakan untuk menghasilkan laba tersebut, atau dengan kata lain ialah menghitungan Profitabilitas.

\section{Harga Emas}

Peningkatan pendapatan masyarakat selalu diimbangi pertumbuhan kebutuhan investasi. Salah satu bentuk investasi yang menawarkan keamanan dan kepastian imbalan yakni logam mulia seperti emas. Kelebihan lain dari investasi emas adalah bahwa emas bisa dijadikan alat untuk diversifikasi dan lindung nilai (hedging) asset. Patokan harga emas dunia menggunakan kurs dolar Amerika Serikat yang dianggap mata uang yang paling stabil, sehingga dengan investasi emas ini investor memperoleh dua keuntungan yakni kenaikan kurs dolar dan emas. Dalam penelitian Fei \& Kelichi (2010) menyatakan bahwa emas memiliki common-wisdom "theories" yakni: (1) Orang menganggap emas merupakan symbol kekayaan abadi. Emas merupakan "safe heaven" dalam pasar keuangan, (2) Emas merupakan "nilai lindung inflasi". Emas banyak dipilih sebagai salah satu bentuk investasi karena nilainya cenderung stabil dan naik. Emas adalah alat yang dapat digunakan untuk menangkari inflasi yang kerap terjadi setiap tahunya. Ketika akan berinvestasi, investor memilih investasi yang memiliki tingkat imbal balik yang tinggi dengan risiko tertentu atau tingkat imbal balik tertentu dengan risiko yang rendah. Investasi di pasar saham tentunya lebih beresiko daripada berinvestasi di emas, karena tingkat pengembalianya yang secara umum relative lebih tinggi dari emas. Menurut Fahmi (2012) emas dikenal memiliki macam bentuk, yakni: (1) Emas Batangan: Emas batangan adalah emas yang masih dalam bentuk asli dan belum dibentuk. Emas kategori ini memiliki nilai yang lebih tinggi di banding emas yang lainya; (2) Emas Koin: Emas koin adalah emas yang sudah dibentuk menjadi koin dan diedarkan ke pasaran untuk dijadikan sebagai salah satu alat ukur dalam setiap transaksi jual beli barang. Emas koin saat ini tidak dianggap representative lagi sehingga penggunaan emas koin ditiadakan, (3) Emas Perhiasan: Emas perhiasan adalah emas yang 
sudah dibentuk menjadi perhiasan dan komposisi emasnya sudah mengalami penurunan, karena emas murni sulit dibentuk menjadi perhiasan.

\section{Hipotesis \\ Hubungan Profilabilitas dengan Nilai Perusahaan}

Profitabilitas merupakan salah satu rasio yang sering digunakan untuk menilai kinerja perusahaan. Profitabilitas didefinisikan sebagai kemampuan perusahaan memperoleh oaba dalam hubungannya dengan penjualan, total aktiva dan modal sendiri. Semakin tinggi kinerja keuangan yang dapat di interpretasikan melalui profitabilitas, maka semakin tinggi pula nilai perusahaan. Dalam teori signalling menyatakan bahwa perusahaan yang berkualitas baik dengan sengaja akan memberikan sinyal pada pasar, dengan demikian pasar diharapkan dapat membedakan perusahaan yang berkualitas baik dan buruk. Melalui rasio profitabilitas perusahaan dapat menilai tingkat keberhasilan manajemen perusahaan mengelola aset dan modal yang dimilikinya untuk menghasilkan laba. Penelitian yang dijadikan acuan diantaranya adalah penelitian yang dilakukan oleh Omran \& Ragab (2004), ditemukan bahwa ROE merupakan rasio keuangan yang signifikan dan merupakan variabel yang paling umum untuk dikaitkan dengan harga saham. Stern (1993 menyatakan pula bahwa ROE merupakan parameter yang paling berkorelasi dengan harga saham.

\section{Hubungan Langsung ROE terhadap Nilai Perusahaan}

Hubungan langsung atau tidak langsung ROE dengan Nilai perusahaan

Dalam teori Pemikiran dari Mishkin, Fredeci, mengatakan bahwa harga emas dapat dijadikan variabel moderasi seperti dalam Teori Permintaan. Hal ini terdapat perlawawan dengan penekanan kebijakan fiscal yang dilakukan oleh ahli ekonomi Keynesian, Fredman beranggapan bahwa uang dan barang merupakan substitusi artinya masyarakat akan memilih keduanya ketika memutuskan berapa banyak uang yang harus dipegang. Hal ini menyebabkan teori Fredman memasukkan perkiraan tingkat pengembalian dari baarang relatif terhadap uang sebagai varaianel dalam fungsi permintaan. Dengan asumsi bahwa uang dan barang merupakan barang substitusi yang menunjukkan bahwa perubahan jumlah uang mempunyai dampak langsung pada pengeluaran agregat. Harga emas dijadikan sebagai variabel moderasi dikarenakan antara harga emas dengan harga saham akan saling berpengaruh. Hl yang mendasari bahwa emas merupakan salah satu alternatif investasi yang cenderung aman dan bebas resiko. Emas dan saham merupakan jenis barang yang bersifat barang substitusi. Pada saat ini emas sebagai alternatif investasi bagi para investor yang tidak ingin berinvestasi dalam sektor uang. Investasi dalam bentuk emas merupakan bentuk investasi komoditas yang sangat likuid dibanyak negara dapat diterima. Oleh sebab itu alasan harga emas dapat diduga akan memperkuat atau memperlemah variabel independen ROE dalam 
memengaruhi Nilai Perusahaan (Tobin's Q) pada perusahaan sektor Perbankan yang terdaftar di BEI.

\section{METODE PENELITIAN \\ Objek Penelitian}

Objek penelitian ini adalah perusahaan Sektor Perbankan yang terdaftar di Bursa Efek Indonesia (BEI) periode 2013-2018.

\section{Jenis Penelitian}

Jenis penelitian yang digunakan adalah penelitian Exploratory (penjelasan). Eksploratif penting untuk memperoleh pengertian yang baik mengenai fenomena perhatian dan untuk melengkapi pengetahuan lewat pengembangan teori lebih lanjut dan pengujian hipotesis. Kemudian dilihat dari pendekatan analisisnya, metode yang digunakan dalam penelitian ini adalah pendekatan kualitatif. Sifat penelitian ini adalah replikasi pengembangan, yaitu penelitian pengulangan dari penelitian- penelitian terdahulu yang serupa namun dengan sampel, variabel, dan periode yang berbeda. Perbedaan penelitian ini dengan sebelumnya terletak pada perusahaan yang diteliti, periode waktu dalam melakukan analisis, dan juga variabel-variabel yang diteliti. Data diperoleh dari Publikasi laporan keuangan tahunan perusahaan Sektor Perbankan yang diperoleh secara elektronik dari situs Internet, Daftar Profitabiltas dan kinerja perusahaan yang menjadi sempel dalam penelitian ini melalui situs Internet,_Publikasi daftar harga emas melalui situs internet.

\section{Metode Pengumpulan Data}

Metode yang digunakan dalam penelitian ini adalah metode dokumentasi yang menyangkut tentang hal-hal dan dokumen yang terkait dengan variabel penelitian. Data yang diperlukan dalam mengukur ROE dan Kinerja Perbankan Tobin's Q diambil dari laporan keuangan perusahaan yang tercantum dalam laporan tahunan, sedangkan harga emas dilihat dari rata-rata harga emas dan diambil dari situs Internet.

\section{Populasi dan Sampel Penelitian}

Populasi dalam penelitian ini adalah perusahaan-perusahaan yang termasuk kedalam Sektor Perbankan dalam bursa efek Indonesia untuk periode 2013-2018. Untuk pengambilan sampel penelitian ini dilakukan dengan teknik purposive sampling, teknik ini dilakukan dengan cara menyeleksi anggota populasi dengan kriteria tertentu. Kriteria - kriteria yang pada penelitian ini sebagai berikut: (1) Menerbitkan laporan keuangan per 31 Desember (2) Memperoleh laba dan nilai kinerja (3) Data harga saham secara lengkap. Sampel yang diperoleh dari Jumlah populasi 40 dan tidak list 11 menghasilkan sampel 29 perusahaan. 


\section{Variabel Penelitian dan Definisi Operasional}

Variabel yang digunakan dalam penelitian ini adalah sebagai berikut:

\section{Variabel Independen (X)}

Return on Equity (X)

ROE merupakan alat ukur kemampuan perusahaan memperoleh laba yang tersedia para pemegang saham perusahaan. ROE membandingkan laba bersih setelah pajak dengan ekuitas yang telah diinvestasikan pemegang saham perusahaan (V Horne dan Wachowiez, 2005-225) Rasio ini menunjukkan efisiensi pengunaan modal sendiri. Semakin tinggi rasio ini, semakin baik.

$$
\text { Return on Equity }(\text { ROE })=\frac{\text { Laba setelah pajak }}{\text { Equitas }} \times 100 \%
$$

\section{Variabel Moderator (Y)}

Harga Emas

Variabel moderasi adalah variabel yang dapat memperkuat / memperlemah hubungan antara variabel dependen dan variabel independen. Variabel moderator yang digunakan adalah harga emas. Dalam penelitian ini melihat harga emas pada publikasi harga emas melalui situs internate dengan cara melihat harga rata-rata emas setiap tahunya selama 6 tahun.

\section{Variabel Dependen $(Z)$ \\ Tobin's Q (Kinerja Perusahaan)}

Variabel dependen yang digunakan dalam penelitian ini adalah Nilai Tobin's. Tobin's Q menjelaskan bahwa perusahaan merupakan nilai dari aktiva berwujud dengan aktiva tidak berwujudnya. Nilai Tobin's Q untuk perusahaan yang tinggi yaitu lebih besar dibandingkan dengan nilai aktiva perusahaan yang tercatat yang berarati masih ada beberapa aktiva perusahaan yang tidak terukur atau tercatat. Rumus Tobin's Q menurut Klapper dan Love dalam Haosana (2012) merupakan penjumlahan dari ME dan DEBT dibagi dengan TA dimana ME bisa dicari dengan mengalikan jumlah saham biasa yang beredaar di akhir tahun dengan harga penutupan sahama (Closing Price) di akhir tahun.

Penelitian ini menguji tentang hubungan sebab dan akibat sehingga masuk kedalam kelompok penelitian asosiatif. Teknik analisis data yang digunakan adalah analisis regresi linier berganda dengan log melalui variabel moderasi atau MRA (Moderate Regression Analysis). MRA adalah aplikasi dari analisis regresi linier berganda yang persamaan regresinya mengandung unsure interaksi. Berikut ini adalah diagram hubungan variabel independen terhadap dependen melalui variabel moderasi. 


\section{Diagram Hubungan Variabel}

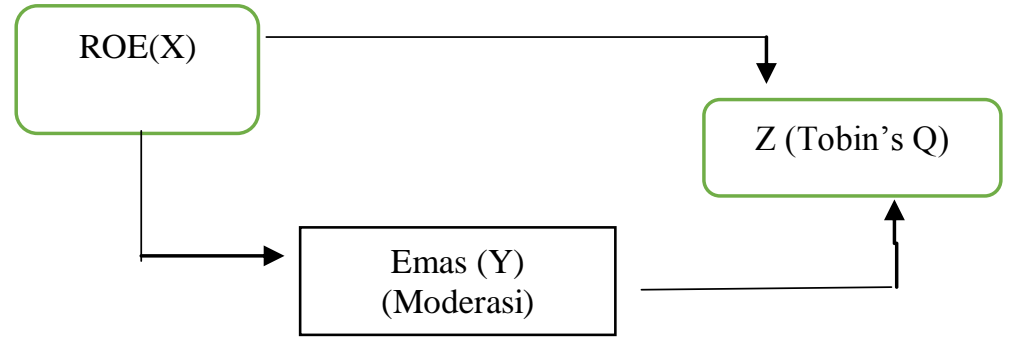

Gambar 1. Sebuah model kerangka berpikir

Berdasarkan gambar tersebut model jalur dihipotesiskan bahwa hubungan ROE pengaruh langsung terhadap Nilai Perusahaan (Tobin's Q), sedangkan Nilai emas diproksikan dengan Nilai Rata-rata harga emas yang mempunyai pengaruh tidak langsung terhadap Nilai Perusahaan (Torbin's Q) dimana dari emas ke profitabilitas baru kemudian ke nilai perusahaan, sehingga hipotesisnya adalah:

$\mathrm{H}_{1}=\mathrm{ROE}$ berpengaruh pada Nilai Perusahaan melalui Nilai Emas

$\mathrm{H}_{2}=\mathrm{ROE}$ berpengaruh tidak langsung pada Nilai Perusahaan melalui Nilai Emas

\section{Uji Asumsi Klasik}

Langkah sebelum regresi untuk diinterpretasikan maka terlebih dahulu diuji apakah terdapat pelanggaran asumsi klasik regresi linier. Dalam penelitian ini akan dilakukan pengujian normalitas, autokorelasi, multikolinearitas, heteroskedastisitas,.

\section{Uji Normalitas}

Uji normalitas digunakan untuk melihat apakah data yang digunakan berdistribusi normal atau tidak. Tingkat kenormalan data dapat berdistribusi normal, karena data berdistribusi normal dianggap dapat mewakili populasi. Dan statistik yang akan digunakan adalah statistic parametrik. Model regresi yang baik adalah memiliki distribusi data normal atau mendekati normal.

\section{Uji Autokorelasi}

Uji autokorelasi bertujuan menguji apakah dalam suatu model regresi linier ada korelasi antara kesalahan pengganggu (residual) pada periode $\mathrm{t}$ dengan kesalahan pada periode t-1 (sebelumnya). Jika terjadi korelasi, berarti ada problem autokorelasi. Autokorelasi muncul karena observasi yang berurutan sepanjang waktu berkaitan satu sama lain. Untuk menguji ada atau tidaknya autokorelasi dapat diuji dengan Durbin Watson. Dalam Durbin Watson hanya digunakan untuk autokorelasi tingkat 1 (first order autocorrelation) dan mensyaratkan adanya intercept (konstanta) dalam model regresi dan tidak ada variabel lagi antara variabel bebas. 


\section{Uji Multikolinearitas}

Uji Multikolinearitas merupakan alat menguji apakah model regresi ditemukan adanya korelasi antara variabel bebas. Model korelasi yang baik seharusnya tidak terjadi korelasi (hubungan langsung) diantara variabel dependen. Jika variabel independen (bebas) saling berkorelasi, maka variabel - variabel ini tidak ortogonal yaitu nilai korelasi antara sesama variabel terikat (independen) sama dengan 0 (nol). VIP (Variance Inflation Factor) merupakan metode dapat digunkan untuk mendeteksi adanya multukolinearitas (untuk menunjukkan adanya hubungan linier antara variabel terikat). Tolerence adalah nilai $1-\mathrm{R}^{2}$ dari regresi antara suatu variabel independen tersebut dengan sisa variabel independen (bebas) lainya. Nilai tolerance yang mendekati 0 (Nol) menyatakan adanya kolinearitas antara suatu variabel bebas tersebut dengan variabel bebas lainya. Batasan yang digunakan adalah 0,1 untuk tolerance yang berarti batas angka 10 untuk VIF.

\section{Uji Heteroskedastisitas}

Heteroskedastisitas terjadi apabila variansi nilai residual tidak konsisten atau berubah-ubah secara sistematik seiring dengan berubahnya nilai variabel independen. Akibat keberadaan heteroskedastisitas adalah menganalisis regresi menghasilkan estimator bias untuk variasi nilai residual dan menimbulkan variansi dalam analisis regresi sehingga uji t, uji $F$ dan estimasi nilai variabel dependen menjadi tidak valid.

Untuk mendeteksi gejala heteroskedastisitas dalam persamaan regresi linier berganda dapat digunakan metode grafik atau scaterrplot di regresi. Metode ini dilakukan dengan melihat grafik plot antara variabel dependen yaitu ZPRED dengan residualnya SRESID untuk melihat ada atau tidaknya pola tertentu pada grafik scaterrplot antara SRESID dan ZPRED. Jika ada pola tertentu seperti titik-titik yang ada membentuk suatu pola tertentu yang teratur (bergelombang, melebar, kemudian menyempit) maka telah terjadi gejala heteroskedastisitas, sebaliknya jika tidak ada pola yang jelas serta titik-titik menyebar diatas dan dibawah angka 0 (nol) pada sumbu Y secara acak, maka tidak terjadi heteroskedastisitas.

\section{Uji Hipotesis}

Pengujian signifikansi variabel secara parsial akan dilakukan uji t. Uji $\mathrm{t}$ digunakan untuk menguji apakah variabel independen berpengaruh terhadap variabel dependen. Selain itu, Uji t dapat digunakan untuk melihat apakah koefisien berbeda secara signifikan dari nol atau tidak. Tahapan uji t adalah sebagai berikut:

Membandingkan nilai hitung dengan $\mathrm{t}$ table

- Ho : $\beta \mathrm{i}=0$, artinya tidak dapat pengaruh yang signifikan antara variabel bebas (ROE terhadap variabel terikat (Kinerja Perbankan) 
- Ha : $\beta \mathbf{i} \neq 0$, artinya terdapat pengaruh yang signifikan antara variabel bebas (ROEterhadap variabel terikat (Kinerja Perbankan)

Menentukan tingkat signifikansi uji $\mathrm{t}$

-Bila tingkat signifikansi uji $\mathrm{t}<\alpha(5 \%)$ maka Ho ditolak dan menerima Ha.

-Bila tingkat signifikansi uji $\mathrm{t}>\alpha(5 \%)$ maka Ho titerima dan menolak Ha.

\section{Uji Koefosien Determinasi $\left(\mathbf{R}^{2}\right)$}

Koefisien determinasi $\left(\mathrm{R}^{2}\right)$ pada intinya mengukur seberapa jauh kemampuan model dalam menerangkan variasi dependen atau dengan kata lain untuk menguji goodness-fit dari model regresi. Nilai koefisien determinasi adalah antara 0 dan 1 . Nilai $\mathrm{R}^{2}$ yang kecil berarti kemampuan variabel-variabel independen dalam menjelaskan variasi variabel dependen amat terbatas (Ghozali, 2009). Nilai yang mendekati 1 berarti variabelvariabel dependen memberikan hampir semua informasi yang dibutuhkan untuk memprediksi variasi variabel dependen. Untuk menghindari bias, maka digunakan nilai Adjusted $\mathrm{R}^{2}$ satu variabel independen ditambah ke dalam model dapat naik atau turun apabila satu variabel independen ditambah ke dalam model.

\section{Pengujian Variabel Moderasi}

Variabel moderasi dibagi menjadi 4 tipe yaitu, Pure Moderator, Quasi Moderator, Homologizer Moderator, dan Prediktor Moderator. Dalam menentukan tipe sebuah variabel moderasi maka harus dilakukan pengujian. Pengujian tersebut dilakukan dengan cara membandingkan nilai beta dari 2 persamaan berikut:

$\mathrm{Y}=\mathrm{a}+\mathrm{bROE}+\mathrm{e}$

$\left.\mathrm{Z}=\mathrm{a}+\mathrm{b}_{1} R O E+\mathrm{b}_{2} \mathrm{Y}\right)+\mathrm{e}$

Pengambilan keputusan untuk menentukan tipe variabel moderasi dilakukan berdasarkan tabel klasifikasi variabel moderasi berikut:

Tabel 1. Klasifikasi Variabel Moderasi

\begin{tabular}{|c|c|c|}
\hline & $\begin{array}{l}\text { Berhubungan dengan } \\
\text { variabel dependen } \\
\text { dan independen }\end{array}$ & $\begin{array}{c}\text { Tidak berhubungan } \\
\text { dengan variabel } \\
\text { dependen dan } \\
\text { independen }\end{array}$ \\
\hline $\begin{array}{l}\text { Tidak berinteraksi } \\
\text { dengan independent }\end{array}$ & $\begin{array}{c}1 \\
\text { Intervening, exogen, } \\
\text { antesenden, prediktor }\end{array}$ & $\begin{array}{c}2 \\
\text { Moderator } \\
\text { (Homologizer) }\end{array}$ \\
\hline $\begin{array}{c}\text { Berinteraksi dengan } \\
\text { independent }\end{array}$ & $\begin{array}{c}3 \\
\text { Moderator } \\
\text { (Quasi Moderator) }\end{array}$ & $\begin{array}{c}4 \\
\text { Moderator } \\
\text { (Pure Moderator) }\end{array}$ \\
\hline
\end{tabular}


Berdasarkan tabel diatas merupakan pendapatan Ghozali, (2009), jika variabel moderator berhubungan dengan kriterion $(\mathrm{Y})$ atau prediktor $(\mathrm{X})$ tetapi variabel moderator tidak berinteraksi dengan prediktor $(\mathrm{X})$ seperti tampak pada kuadran 1, maka variabel $\mathrm{Z}$ bukanlah moderator tetapi merupakan variabel intervening, exogen, anteseden atau prediktor (independen). Secara konseptual variabel pada kuadran 2,3,4 diidentifiksikan sebagai variabel moderator.

Jenis variabel moderator pada kuadran 2 mempengaruhi kekuatan hubungan, tetapi tidak berinteraksi dengan variabel prediktor $(\mathrm{X})$ dan tidak berhubungan secara signifikan baik dengan prediktor (X) maupun dengan variabel kriterion (Y). Dalam keadaan seperti ini, nilai residual atau eror merupakan fungsi variabel moderator. Jenis moderator seperti ini disebut dengan variabel Homologizer.

Jenis kedua dari variabel moderator adalah variabel moderator akan memodifikasi bentuk hubungan antara variabel kriterion $(\mathrm{Y})$ dan prediktor (X) seperti tampak pada kuadran 3 dan 4. Pada kuadran 3, variabel moderator $(\mathrm{Z})$ berhubungan dengan variabel kriterion $(\mathrm{Y})$ atau variabel prediktor $(\mathrm{X})$ serta berinteraksi dengan variabel prediktor $(\mathrm{X})$. Pada kuadran 4 , variabel moderator $(\mathrm{Z})$ tidak berhubungan dengan variabel kriterion $(\mathrm{Y})$ dan prediktor $(\mathrm{X})$ tetapi berinteraksi dengan variabel prediktor $(\mathrm{X})$.

\section{Hasil Dan Pembahasan Hasil Analisis Analisis Statistik Deskriptif}

Analisi ststistik deskriptif bertujuan untuk menguji karakteristik sampel data yang digunakan dalam penelitian serta untuk mengetahui nilai mean, standar deviasi untuk masing - masing variabel. Hasil analisis statistik deskriptif .

Tabel 2. Analisis Statistik Deskriptif

\begin{tabular}{lccc}
\hline \multicolumn{1}{c}{ Variabel } & $\mathrm{N}$ & Mean & Std. Deviation \\
\hline Log ROE $(\mathrm{X})$ & 180 & 1.7764 & 0,23938 \\
Log EMAS $(\mathrm{Y})$ & 180 & 5,7139 & 5,6995 \\
Log_Q(Z) & 180 & 0,0660 & 0,0186 \\
\hline Valid N (listwise) & & 180 &
\end{tabular}

Berdasarkan perhitungan statistik deskriptif pada tabel 1, maka dapat dijelaskan sebagai berikut: 
- Pada variabel X (ROE), nilai mean sebesar 1,7764 dan nilai standar deviasinya sebesar 0,23938 .

- Pada variabel Y (Harga Emas), nilai mean sebesar 5,7139 dan nilai standar deviasinya sebesar 0,03179 .

- Pada variabel Z (Kinerja Perusahaan), nilai mean sebesar 0,0660 dan nilai standar deviasinya sebesar 0,01866

Nilai standar deviasi variabel menunjukkan seberapa jauh variasi datanya, jika nilai standar deviasi lebih besar dari nilai mean dapat diartikan bahwa hasil tersebut tidak baik atau heterogen. Sebaliknya, jika nilai standar deviasi lebih kecil dari nilai mean dapat diartikan bahwa hasil tersebut baik atau homogen. Perhitungan diatas, nilai mean untuk semua variabel lebih besar dari nilai standar deviasinya, berarti dapat disimpulkan bahwa hasilnya homogen yang artinya perbedaan nilai suatu perusahaan dengan perusahaan lain relatif kecil.

\section{Pengujian Hipoteis}

Uji parsial (t) untuk menguji apakah masing - masing variabel independen berpengaruh terhadap variabel dependen. Hal hal ini dapat juga uji interaksi antara variabel independen terhadap dependen dengan variabel pendorong/pelemah oleh variabel moderasi. berikut merupakan hasil regresi yang dilakukan berdasarkan persamaan yang dibuat.

\section{Hasil Uji Parsial}

Berdasarkan hasil perhitungan, maka dapat disusun persamaan regresi adalah sebagai berikut:

$\mathrm{Y}=0,144-046 \mathrm{ROE}+\mathrm{e}(1)$

$\mathrm{Y}=2,790-0,044 \mathrm{ROE}-0,465 \mathrm{EMS}+\mathrm{e}(2)$

Dari hasil pengujian yang telah dilakukan maka dapat dilakukan pengujian hipotesis sebagai berikut:

\section{Pengaruh ROE terhadap Kinerja Pereusahaan (Q)}

Hipotesis yang diajukan adalah sebagai berikut:

$\mathrm{H}_{1}=\mathrm{ROE}$ berpengaruh positif terhadap harga emas.

$\mathrm{H}_{0}=\mathrm{ROE}$ tidak berpengaruh terhadap harga emas

Berdasarkan tabel 14, diketahui bahwa nilai signifikansi 0,135>0,05 dan $\mathrm{t}_{\text {hitung }}$ lebih kecil dari $\mathrm{t}_{\text {tabel }}(-1,498<1,645)$ maka $\mathrm{H}_{0}$ diterima dan $\mathrm{H}_{1}$ di tolak. Hal ini berarti ROE tidak berpengaruh terhadap harga saham. Besarnya pengaruh $\mathrm{X}_{1}$ terhadap $\mathrm{Y}$ adalah sebesar 0,020 (2,0\%). Pengaruh ini bersifat negatif positif yang berarti bahwa ketika ROE mengalami kenaikan maka Kinerja Perusahaan akan terjadi penurunan. 
Harga Emas memoderasi pengaruh ROE terhadap Kinerja Perusahaan Hipotesis yang diujikan adalah sebagai berikut:

$\mathrm{H}_{\mathrm{a}}$ : Harga Emas memoderasi pengaruh ROE terhadap Kinerja Perusahaan (Q)

$\mathrm{H}_{0}$ : Harga Emas tidak memoderasi pengaruh ROE terhadap Kinerja Perusahaan (Q).

Berdasarkan tabel diatas, variabel X_Y merupakan interaksi antara variabel ROE dengan variabel harga emas dan nilainya tidak signifikan yaitu $0,034>0,05$ dan $t_{\text {hitung }}$ lebih lebih kecil dari $t_{\text {tabel }}(-2,125<1,645)$ sehingga $\mathrm{H}_{0}$ ditolak dan $\mathrm{H}_{3 . \mathrm{a}}$ diterima. Hal ini menandakan bahwa variabel harga emas berperan sebagai variabel moderasi antara ROE dengan Nilai Perusahaan (Q Torbin's).

\section{Uji Koefisien Determinasi $\left(\mathbf{R}^{2}\right)$}

Uji koefisien determinasi $\left(\mathrm{R}^{2}\right)$ dibergunakan untuk mengukur seberapa jauh kemampuan model dalam menerangkan variasi dependen atau dengan kata lain untuk menguji goodness - fit dari model regresi. Nilai koefisien determinasi adalah antara 0 sampai 1 . Nilai $\mathrm{R}^{2}$ yang kecil berarti kemampuan variabel - veriabel independen amat terbatas. Nilai yang mendekati 1, maka dapat diartikan apabila variabel - variabel independen memberikan hampir seluruh informasi yang dibutuhkan untuk memprediksi variasi variabel independen.

Berdasarkan hasil pengujian koefisien determinasi, diketahui bahwa nilai dari $R$ Square sebesar $0,0200,004$ atau sebesar 2\%. Hasil ini disimpulkan bahwa Nilai Perusahaan dipengaruhi 2,0\% oleh variabel ROE dan variabel moderator harga emas dan sisanya sebesar $98 \%$ dipengaruhi oleh variabel yang tidak dijelaskan dalam penelitian ini, seperti faktor makro ekonomi, rasio keuangan yang lain, investasi dalam sektor lain..

\section{Pengujian Tipe Variabel Moderasi}

Pengujian tipe variabel moderasi dilakukan dengan cara membandingkan signifikansi beta dalam persamaan berikut:

Tobin's $\mathrm{Q}=\mathrm{a}+\mathrm{bROE}+\mathrm{e}$

Tobin's $\mathrm{Q}=-0,044 \mathrm{ROE}+\mathrm{e}$

Tobin's $\mathrm{Q}=\mathrm{a}+\mathrm{b}_{1} \mathrm{ROE}_{\mathrm{i}}+\mathrm{b}_{2} \mathrm{EMS}_{2}+\mathrm{e}$

Tobin's $\mathrm{Q}=2,798-0,044$ Roe $-0,465 \mathrm{Ems}+\mathrm{e}$

Berdasarkan perhitungan 2 persamaan diatas dihasilkan bahwa nilai signifikansi b2 adalah 0,034>0,05 yang berarti nilai ini tidak signifikan, yang berarti ini signifikan. Y sebagai variabel moderasi signifikan. Dan juga variabel $\mathrm{ROE}(\mathrm{X})$ sebagai variabel interaksi antara $\mathrm{ROE}$ dan vareiabel 
moderasi Harga Emas ternyata Signifikan sehingga dapat disimpulkan ke dalam pure moderator.

\section{Pembahasan Hasil Penelitian \\ Pengaruh variabel ROE Terhadap Nilai Perusahaan}

Hasil uji parsial yang menunjukkan bahwa nilai $t_{\text {hitung }}$ lebih kecil dari $\mathrm{t}_{\text {tabel }}(-0,1498<1,645)$ dan tingkat signifikansinya lebih tinggi dibandingkan dengan nilai probabilitasnya $(0,135>0,05)$. Nilai koefisien regresi variabel ROE sebesar -0,0465 . Hal ini menunjukkan bahwa ketika nilai ROE naik 1 maka Nilai Perusahaan akan turun sebesar 0,0465. Hasil pengujian ini menolak hipotesis $\mathrm{H}_{1}$ yang menyebutkan bahwa ROE tidak berpengaruh terhadap Nilai Perusahaan berarti $\mathrm{H}_{1}$ ditolak

Hasil penelitian ini tidak sejalan dengan Wahyudi Asto Nugroho (2012), bahwa ROE terdapat pengaruh terhadap nilai perusahaan, pada kenyataan ini mengindikasikan bahwa, ekspektasi dari ekuitas yang diharapkan sesuai dengan kenyataan akan meningkatkan nilai perusahaan. Kondisi lingkungan dan pesaing yang ada sulit diprediksi seringkali memberikan sentimen negatif pada peningkatan nilai perusahaan meskipun return yang diharapkan memiliki kecenderungan meningkat (Husnan, 2005). Berarti pada posisi penolakan bahwa ROE tidak berpengaruh pada Nilai perusahaan perlu adanya evaluasi lebih lanjut.

Pengaruh variabel ROE terhadap Nilai Perusahaan dimoderasi oleh harga emas.

Pengujian variabel ROE terhadap Nilai Perusahaan yang dimoderasi oleh harga emas menunjukkan hasil ada pengaruh. Hasil uji parsila menunjukan bahwa nilai t hittiung ROE -1,498 < 1,645 lebih kecil dan tingkat signifikansi lebih kecil dari nilai probitabilitas $(0,000<0,05)$ hitungan Emas -2,125 < 1,645 lebih kecil dan tingkat signifikansi lebih kecil dari probabilitas $(0,034<0,05)$ menunukkan bahwa harga emas berpengaruh terhadap Nilai perusahaan. Pada hasil pengujian ini menerima $\mathrm{H}_{2}$ yang menyatakan bahwa harga emas memoderasi pengaruh terhadap Nilai Perusahaan.

Pada tingkat ROE yang tinggi pada perusahaan perbankan, akan menarik investor dalam berinvestasi. Perusahaan perbankan yang memiliki ROE tinggi adalah perusahaan yang mampu menjaga kepercayaan nasabahnya untuk menyimpan dana yang dimiliki pada bank tersebut. Sehingga dapat dimungkinkan investor juga akan tertarik untuk berinvestasi pada perusahaan dan dapat meninggkatkan nilai saham perusahaan tersebut. Namun kadang kala investor juga mempertimbangkan investasi lain seperti emas, emas yang diakui memiliki tingkat resiko yang rendah lebih menguntungkan untuk dijadikan alat investasi. 
Variabel harga emas dapat memperkuat atau memperlemah hubungan antara variabel ROE dengan harga saham. Hal ini disebabkan dengan variabel harga emas yang berhubungan dengan ROE dan harga saham namun tidak berinteraksi dengan harga saham. Bila dilihat dari koefisien regresi yang bernilai negatif, maka ketika harga emas tinggi akan memperlemah hubungan antara ROE dengan harga saham atau nilai perusahaan. Hasil regresi yang signifikan menegaskan bahwa variabel harga emas berperan sebagai variabel moderasi. HaL ini dapat dijelakan bahwa hasil 1 independen dan 1 dependen pada $\mathrm{Q}_{1}=0,147-0,046$ berarti $\mathrm{ROE}$ berpengaruh negatifpositif terhadap Q (Kinerja Perusahaan) dan penjelasan 2 independen dan 1 dependen dengah pada $\mathrm{Q}_{2}=2,798-0,044 \mathrm{ROE}-0,465$ Ems berarti ROE terhadap Tobin's $Q$ pengaruh negatif yang tidak signifikan sedangkan Emas terhadap Tobin's Q pengaruh negatif yang signifikan, Koefisien tidak langsung adalah $(-0,046 \mathrm{X}-0,465)=0,02139$ dan Pengaruh Total adalah $-0,044+(-0,046 X-0,465)=-0,02261$. Angka Pengaruh Total -0,02261 ini lebih besar hubungan langsung -0,044, maka hubungan yang sebenarnya adalah tidak langsung lebih baik mempengaruhi Tobin's Q (Nilai Perusahaan) yang berarti secara tidak langsung variabel emas dapat mendorong pengaruh terhadap Kinerja Perusahaan sehingga variabel moderat emas jika harga emas cendrung tinggi maka kinerja perusahaan sektor perbankan untuk sebagian akan semakin melemah, oleh karena investornya akan mempertimbangkan investasinya pada sektor riil berupa investasi emas disamping investasi dalam bentuk saham lain yang kinerja perusahaan baik.

\section{Simpulan}

Berdasarkan hasil penelitian mengenai analisis variabel moderasi harga emas terhadap hubungan return on equity terhadap nilai perusahaan yang menunjukkan adanya pengaruh implikasi hasil penelitian yang dapat diberikan pada Investasi pada sektor perbankan cenderung berbeda dari sektor lain pada umumnya, dikarenakan pada sektor perbankan para investor lebih menyukai rasio ROE yang relatif tinggi dengan pertimbangan efisiensi penggunaan modal sendiri. Oleh karena itu perusahaan pada sektor perbankan harus mengoptimalkan rasio ROE dalam pengelolaan perusahaan agar menarik para investor untuk berinvestasi.

Dalam penelitian ini, menggambarkan bahwa investor tidak menilai perusahaan dari rasio pembagian deviden, namun pandangan investor akan lebih luas dalam meneliti suatu perusahaan. bukan hanya dari deviden yang dibagikan, maupun besarnya risiko yang ditanggung namun juga memikirkan faktor lain seperti isu kenaikan harga emas yang sedang berkembang di masyarakat ataupun faktor makro ekonomi perubahan kurs mata uang atau yang memberikan pengaruh negatif dan signifikan (khususnya harga emas) yang dapat mempengaruhi penilaian investor. 
Faktor eksternal dari perusahaan terlihat kuat mempengaruhi pengambilan keputusan investor khususnya harga emas, jika harga emas cenderung menaik maka kinerja perbankan perlu kehati-hatian karena harga emas akan mengakibatkan kinerja sektor perbankan cenderung melemah. Hal ini akan memberikan dampak pada para investor tersedia dan fluktuasi harga saham yang terjadi di pasar modal merupakan juga akan memberikan pengaruh dalam pengambil keputusan investor berdasarkan informasi non rasional yang pasti.

\section{DAFTAR PUSTAKA}

Brigham, Eugene F dan Houston, Joel F (2011). Dasar-Dasar Manajemen Keuangan Edisi 11, Jakarta: Salemba Empat

Fahmi, Irham. (2012). Pengantar Manajemen Keuangan Teori dan Soal Jawab. Bandung:Alfabeta.

Fei, Fan \& Adbie, Kelechi. (2010). Theories of Gold Movements : Common Wisdom or Myths?, Undergraduate Economic Review: Vol.6 : Article 5.

Ghozali, I. (2009), Ekonometrika : Teori, Konsep dan Aplikasi dengan SPSS 17. Semarang: Badan Penerebit - Undip.

Husnan Suad. 2001). Dasar-Dasar Teori Portfolio dan Analisa Sekuritas. Yogyakarta: AMP YKPN.

Husnan, Suad. 2006. Teori dan Penerapan (Keputusan Jangka Panjang) Edisi Keempat. Yogyakarta: BPFE Yogyakarta.

Khatab dkk, 2011. Corporate Governace and Firm Performance : Case Study of Karachi Stock Market International Journal Trade. 2 (1)

Mishkin, Fredeci S, (2009). The Economic of Money, Banking and Financial Markets Edisi 8. Jakarta : Salemba Empat.

Mishra, P.K., Das, J. R., \& Mishra, S. K. (2010). Gold Price Volatility and Stock Market Return in India. American Journal of Scientific Research, 47-55.

Omran, M., \& Ragab, A. (2004). Linear versus non-linear relationships betwen financial ratios and stock return. Review of Accounting and Finance. Review of Accounting and Finance, 3 (2), 84-102.

Ranson, D., \& Wainwright, H (2005). Inflation Protection: Why gold works better than "liknkers". World Goald Council, 1-9.

Sambodo, Bayu Seto (2014). Analisis Pengaruh inflasi. BI Rate, Nilai Tukar dan Harga Emas Dunia Terhadap Indeks Harga Saham Sektor Pertambangan di BEI.

Sarfaraz, L. \& Afsar, A. (2005) A Study On The Factor Affecting Gold Price and A Neurofuzzy Model of Forecast [online]. University Library of Munich: MPRA Paper. 
208 Akutansi Bisnis dan Manajemen (ABM) Vol. 26, No. 2, Oktober 2019

Siahaan, Fajar O.P. 2013. The Effect of Good Corporate Governace Mechanism, Leverage and Firm Size Value. GSTF Journal on Business Review (GBR) 2 (4)

Stern, J. (1993), Value and People Managemen. Corporate Finanse

Sudana, I Made. 2009. Manajemen Keuangan Teori dan Praktik. Surabaya: AUP

Sugiono, (2017). Metode Penelitian Pendidikan Pendekatan Kuantitatif, Kualitatif, dan R\&D. Bandung; Alfabeta.

Sugiyono, (2001). Metode Penelitian Bisnis. Bandung. Alfabeta

Sunaryah (2006). Pengantar Pasar Modal, Yogyakarta:UPP STIM YKPN

Van Horne, C. James dan Wachiwicz, M. John. (2005). Prinsip-prinsip Manajemen Keuangan, Edisi 12. Jakaertra : Salemba Empat.

Wahyudi Asto Nugroho (2012). Pengaruh Profitabilitas, Likuiditas da Leverage Terhadap Nilai Perusahaan. Artikel Program Studi Megister Manajemen Program Pasca Sarjana, Universitas Muhamadiyah Surakarta 